\title{
An Analysis on the Ideological and Political Theories Teaching in All Courses in Higher Mathematics Teaching
}

\author{
Weili Liu ${ }^{1, *}$, Huimin $\mathrm{Lu}^{1}$ and Jun $\mathrm{Xie}^{1}$ \\ ${ }^{1}$ Dept. of Basic Science, Dalian Naval Academy, Dalian 116018, China \\ * Corresponding author. Email: 648746489@qq.com
}

\begin{abstract}
In order to better integrate ideological and political elements into the classroom, this paper, based on the requirements of ideological and political teaching and existing teaching experience, analyzed the curriculum ideological and political teaching environment, including resources environment and aesthetic environment. Then, this paper analyzed how to explore ideological and political elements from mathematical concepts, mathematical modeling, the concept of definite integration, mathematical practice, mathematical history, etc. And through teaching cases to explain how to naturally integrate ideological and political elements in the classroom; Through teaching practice, the method effectively integrates the classroom and achieves the expected effect. Of course, in the implementation of curriculum ideological and political teaching, we still face some problems, such as how to balance the relationship between teaching content and curriculum ideological and political teaching, which requires scholars to continue to study.

Keywords: ideological and political theories teaching in all courses; higher mathematics; teaching case;
\end{abstract}

teaching environment; education

\section{INTRODUCTION}

In order to do a good job in the ideological and political work of college students, General Secretary Xi Jinping stressed at the National Conference on Ideological and Political Work in Colleges and Universities to make good use of the main channels of classroom teaching, to coordinate various courses and ideological and political theory courses to the same direction, to form a synergistic effect[1].In recent years, the Ministry of Education has promoted the classroom teaching reform of "curriculum ideological and political" in universities, and integrated ideological and political education elements and ideological and politics in various courses into curriculum teaching, integrating curriculum knowledge and ideological and political education in classroom teaching[2]. The curriculum ideological politics here is not simply adding a new ideological and political education activity to the classroom teaching, but the organic integration of ideological and political education objectives and curriculum content teaching.

As one of the necessary professional basic courses of science and technology in college undergraduate education, the content of higher mathematics course plays an important position in the knowledge system of college students, which determines that higher mathematics will undertake the important ideological and political tasks of the course[3]. Because the history of mathematics, mathematics aesthetics and mathematics allusions, mathematics content and ideological and political content in the higher mathematics courses themselves have a certain compatibility[4]. As long as the teachers of higher mathematics curriculum continue to explore and reform penetration, it will make the content of higher mathematics curriculum organically integrated with the curriculum ideological and political integration, making the higher mathematics curriculum teaching one of the main channels of curriculum ideological and political education.

\section{CREATE A TEACHING ENVIRONMENT FOR IDEOLOGICAL AND POLITICAL THEORIES TEACHING IN HIGHER MATHEMATICS COURSES}

\subsection{Create a Resource Environment for Ideological and Political Theories Teaching}

The construction of ideological and political education in higher mathematics courses is first to build a good ideological and political resources and environment. And all the teachers teaching higher mathematics can determine 
the ideological and political materials, integration methods and goal formulation, etc. The specific teaching materials have a wide range, such as mathematics development history materials, teaching courseware, computing simulation procedures, research literature, etc. This is a grand teaching research project, which requires all higher mathematics teachers to offer suggestions to build ideological and political resources environment[5].

The higher mathematics curriculum resource database established by higher mathematics teachers can adopt the principle of combining construction and timely object modification, and learn from the excellent teaching resources in other curriculum resource database for integrated teaching; and support mixed teaching and flipped classroom and other advanced teaching modes to achieve the effect of teaching higher mathematics content and ideological and political education.

There are many software involved in higher mathematics curriculum teaching, which can visualize the abstract concepts in curriculum teaching, but also realize computational simplification, and lay the foundation for the application of students' future knowledge[6].The development of all mathematics involved in the curriculum teaching can let students understand the application of mathematics in computer and engineering[7].It can also introduce the commercial value of mathematical software and the research and development of mathematical software at home and abroad, so that students can establish their confidence and determination to learn technology. At present, our common mathematical software in mathematics has the following aspects: can comprehensively solve numerical computing, algebraic operation and graph editing functions is MATLAB, MATHEMATICA, MAPLE; statistical mainly SAS, PYTHON, SPSS, EVIEWS; mathematical planning software mainly uses LINGO, LINDO; engineering computing software mainly includes NASTRAN, ANSYS. The use of these software can be introduced in the different teaching contents of higher mathematics, and good results can be achieved from different perspectives according to the ideological and political teaching objectives of the courses.

\subsection{Create an Aesthetic Environment for Ideological and Political Theories Teaching}

Course aesthetic environment can be created from multiple angles, such as using fine ancient Chinese poetry is also a good direction, higher mathematics, can recite the tang dynasty famous poet li bai "yellow crane tower send Meng Haoran straight" in the poem "solitary sail far, only see the Yangtze river sky" to show infinite characteristics in a romantic and beautiful way, its teaching picture also poetry, let students feel the profound traditional Chinese culture, let students feel the cultural confidence of the Chinese nation[8].There are many such poems in ancient Chinese poems, explaining mathematical ideas and mathematical principles from different perspectives. For example, the song dynasty writers "west wall" in the poem "horizontal as mountain peak, far and low" the two sentences corresponding picture can be used as a multivariate function of the extreme point and the highest point of the picture, beautiful picture can attract students concentrate on learning course, at the same time the high and low that mountain and canyon also represent the extreme value and the most intuitive interpretation[9].There are many aesthetic environments in higher mathematics, such as formula beauty, simplicity beauty, etc. Different content can always find different aesthetic environments.

\section{ANALYSIS OF TEACHING CASES ABOUT IDEOLOGICAL AND POLITICAL THEORIES TEACHING IN HIGHER MATHEMATICS COURSES}

\subsection{Dig into the Ideological and Political Elements from the Mathematical Concepts}

Most of the ideological and political elements in higher mathematics content are not easy in the textbooks, which requires us to be familiar with the profound connotation of ideological and political education, on the other hand, fully explore the ideological and political thoughts implied in higher mathematics courses, many of which mathematical concepts are good ideological and political themes. For example, the opening content of higher mathematics, "Extreme", is suitable for cultivating college students' cultural confidence and national self-esteem, and stimulating their patriotism. As early as in ancient China, "Zhuangzi - the World" recorded " take half from a foot long stick each day, you will never exhaust it in million years."And the great mathematician of the Wei and Jin dynasties and the outstanding mathematician in the Southern and Southern Dynasties calculated the limit, a method more than 1,000 years earlier than the European limit thought[10].Through the introduction of the development of ancient mathematics in China, the introduction of ideological and political content is relatively natural, and can stimulate students' desire for knowledge.

In addition to the derivative concept and many mathematical concepts of ideological and political education significance, such as the derivative definition contains the dialectical relationship between quantitative and qualitative change, use these contents can educate students humanistic quality and dialectical thinking unity, and further cultivate their attitude towards scientific attitude and spirit is to be objective and rigorous, dare to explore. 


\subsection{Dig into the Ideological and Political Elements from Mathematical Modeling}

Mathematics familiar Kemack and Mckendrick infectious disease dynamics system model, such as in well-known SIR model derivatives are a function of the rate of time, they establish the premise is to admit things are changing, and our mathematics is not only acknowledging its change, but also in mathematical language to describe its change, and then predict the peak time of infectious disease through mathematical theory, infection scale. Then use the optimized theory to give preventive programs, and thus protect humans. There are many ideological and political elements, such as the development and change of things, and the twists and turns of things' development can be found through numerical simulation. Using mathematical modeling for ideological and political education certainly has many advantages over empty theories.

\subsection{Dig into the Ideological and Political Elements from the Idea of Definite Integral}

The computational idea of a definite integral is four steps "partition-approximation-sum-take limit". Through a mathematical introduction to its definition, you can also calculate the value of the fixed integral, that is, the area of the trapezoid of the curved edge on the interval. It is introduced step by step during the solution process. The first step divides: divide the insertion of the integral interval into several points to form a small interval of equal length to form several curved trapezoids; the second step approximation is the internal rectangle of each curved trapezoidal shape; the third step sums: all internal matrix area and the curved trapezoidal approximate area; the fourth step limit: obtain the whole fixed integral value is the area value of the curved trapezoid. In the explanation of this example, we can extend them to solve complex problems, and we can break down complex things into simple things to solve them, and then combine them again. Thus introducing the philosophical idea of mass accumulation, quantitative change causes qualitative change.

\subsection{Dig into the Ideological and Political Elements from the Practical Knowledge of Higher Mathematics}

Higher mathematics course although very theoretical, but it is abstract from practice, so has a strong application background, textbooks have some knowledge background and application knowledge, teachers can connect this background with the current economic and current politics let students know that learning cultural knowledge is not only to change personal destiny and realize life value, is also the main tool to realize the rejuvenation of the Chinese nation. For example, using the limit of economics compound interest model, using compound interest model for example to let students understand different time stages of production data and production capital conversion relationship, at the same time further extended compound interest model application in investment, life, in further abstract the compound interest model thinking in the field of ideological and politics, Thus to stimulate the students' enthusiasm for learning, cultivate their patriotic enthusiasm.

\subsection{Dig into the Ideological and Political Elements from the History of Mathematics}

The history of Chinese mathematics began around 4000 BC, the earliest Neolithic Yangshao settlement sites with circles, squares; decimal in oracle; Liu Hui; Southern Song Dynasty mathematician Yang Hui Triangle; Shen Kuo in Northern Han Dynasty; Qin shao and Nine; and Ming Dynasty scientist $\mathrm{Xu}$ Guangqi is famous for his mathematical translation of Geometry Originally[11].

Modern mathematician Li Shanlan power sum formula with natural number; Xiong Qinglai and Xiong Shi infinity; differential geometry. The mathematical achievements made by Chen Provincial, mathematicians Hua Luogeng and Chen Jingrun, all are shocking. These themes can undoubtedly educate contemporary college students to enhance their national pride and confidence, and set up the ambition to contribute to the socialist modernization construction when they grow up.

Of course, the history of mathematics is indispensable to the history of foreign mathematics. For example, explaining the concept of integral cannot tell the story of two British scientist Newton and German mathematician Leibnitz about the invention of calculus. This scientific debate caused a long-term opposition between continental mathematicians and British mathematicians, and led to British mathematicians in a fairly long period because of Newton's "flow counting" stopped, has refused to use Leibniz invented calculus symbols and results, causing the mathematical development greatly behind the mainland. This history of mathematics can educate college students to abandon the narrow "patriotism", have a scientific spirit, and be good at making use of the existing achievements of human civilization. At the same time, there are many interesting, inspirational and educational characters and stories in the history of foreign mathematics. The introduction of these contents into the classroom can undoubtedly increase the effect of classroom teaching and improve students' interest in learning.

\section{PROBLEMS AND COUNTERMEASURES IN HIGHER MATHEMATICS TEACHING}

Curriculum ideological and political education is a major change of ideological and political education from "special teaching" to "everyone teaching". It requires all teachers in universities to cooperate closely to form a joint force to achieve this goal. Curriculum ideological and political 
education of higher mathematics courses is an important part of this goal, which faces some problems in the implementation and needs to be targeted.

\subsection{The Combination of Higher Mathematics Content and Ideological and Political Education}

Although we have illustrated examples of the rationality of the integration of ideological and political education in several knowledge points, there are many contents of higher mathematics and need to be integrated into ideological and political education. How to make the two combines well?

The way to solve this problem is to make all the higher mathematics course teachers explore the content of the teaching materials, find the ideological and political elements corresponding to each mathematics knowledge point, and compile them into the teaching textbooks. Of course, in the process of finding the ideological and political elements of higher mathematics courses to communicate with the ideological and political teachers, so as to find a better way of higher mathematics and ideological and political integration.

\subsection{Knowledge of Ideological and Political Theories Teaching in Higher Mathematics Courses}

A small number of higher mathematics teachers have an inadequate understanding of ideological and political courses, resulting in the effect of practice is not ideal.

For this problem, first, strengthen publicity, to create a good curriculum ideological and political environment. Second, higher mathematics teachers should change their thoughts, raise awareness, adhere to cultivating people by virtue, and realize the glorious mission of teaching and educating people.

\section{CONCLUSION}

As a public course of higher education, higher mathematics curriculum carries a lot of ideological and political information, which needs us to dig and systematize. At the same time, it can combine with The Times and produce collaborative education benefits with ideological and political theory courses. The primary task to achieve this goal is to first establish an ideological and political education environment in the higher mathematics curriculum. Secondly, higher mathematics course teachers are required to find the entry point in the teaching content to construct the curriculum ideological and political sports department, give full play to the educational function of higher mathematics courses, and implement the educational responsibility of higher mathematics teachers.
Compared with higher mathematics courses, it is more difficult to integrate ideological and political education into other liberal arts courses. In the implementation process, we should consider systematicness and coherence, play a long-term mechanism, implement it in batches according to the actual situation of each school, and promote it after obtaining experience. How effective is it being? Need to constantly practice, summarize experience, improve the effect.

\section{ACKNOWLEDGMENT}

Fund Project: Education and Scientific Research Project of Dalian Naval Academy

\section{REFERENCES}

[1] Xi Jinping. Implementing the ideological and political work of the whole process of education and teaching creates a new situation for the development of higher education in China [N]. Guangming Daily, 201612-09 (01).

[2]Feng Gang. Enhance the endogenous driving force for the sustainable development of ideological and political education in colleges and universities[J]. China Higher Education ,2017(2):25-29. (In Chinese)

[3] Gaoming. Exploration of ideological and political teaching in higher mathematics courses[J]. Journal of Tianjin Academy of Education and Science, 2019(3): 60-66. (In Chinese)

[4]Dong Minghui. A Study on "Curriculum ideological and political affairs" in colleges and universities[D]. Dalian: Dalian Maritime University,2019. (In Chinese)

[5] Liu Chenggong. Some thoughts on promoting "curriculum ideological and political affairs" in colleges and universities [J]. Ideological and Theoretical Education, 2018 (6): 62-67. (In Chinese)

[6] Wang Huiling. Exploration of course ideological and political integration into professional course teaching $[\mathrm{J}]$. Corporate Education, 2018 (10).

[7] Lv Ning. Thoughts of "ideological and political curriculum" and "curriculum ideological and politics" [J]. University Education, 2018 (1).

[8] Wang Qian. Exploration of the teaching reform of curriculum ideological and political integration into higher vocational mathematics [J]. Journal of Beijing Polytechnic Vocational and Technical Institute, 2020,19 (1): 83-86. 
[9] Qin Houorong, Xu Hairong."Touch" and teaching system construction of university mathematics courses [J]. Chinese University Teaching, 2019 (9): 61-64.

[10] Xu Yadan. Preliminary discussion on the practice of ideological and political education in higher vocational mathematics course-taking the binomial distribution teaching as an example [J]. Journal of
Jiangxi Electric Power Vocational and Technical College, 2020, 33 (4): 85-86. (In Chinese)

[11] Zheng Yi. Thinking and practice of "curriculum ideological and political affairs" in university mathematics [J]. Journal of Ningbo Education Institute, 2019, 21 (1): 59-61. (In Chinese) 